IJMS 16 (2), 123-153 (2009)

\title{
THE EFFECTIVENESS OF LOCATION INCENTIVE: AN ANALYTICAL STUDY OF MANUFACTURING SMEs IN THE KEDAH STATE
}

\author{
SOON JAN JAN \\ ASAN ALI GOLAM HASSAN \\ LIM HOCK EAM \\ College of Arts and Sciences \\ Universiti Utara Malaysia
}

\begin{abstract}
The main objective of this research is to find out the effectiveness of location incentive in attracting Small and Medium Enterprises (SMEs) to a certain industrial location in the state of Kedah. The location choice identified in this research would be Sungai Petani and non-Sungai Petani industrial areas. By using the logit model, we found that location incentive is not as effective as other factors in attracting SMEs in setting up their establishments in Kedah. The important factors that influence the location choice of manufacturing SMEs are (i) the years of operation of an SME, and (ii) the physical distribution of an SME product.
\end{abstract}

\begin{abstract}
ABSTRAK
Objektif utama kajian ini adalah untuk mengkaji keberkesanan insentif lokasi dalam menarik firma-firma Industri Kecil dan Sederhana (IKS) ke lokasi industri tertentu di negeri Kedah. Lokasi pilihan yang telah dikenal pasti ialah kawasan perindustrian di Sungai Petani dan bukan Sungai Petani. Dengan menggunakan model logit, kami dapati insentif lokasi tidak seberkesan jika dibandingkan dengan faktor lain dalam menarik IKS untuk mendirikan firmafirma mereka di Kedah. Faktor-faktor penting yang mempengaruhi pilihan lokasi firma-firma IKS ialah (i) jumlah tahun beroperasi sesuatu firma IKS, dan (ii) pengagihan fizikal produk firma IKS tersebut.
\end{abstract}

Keywords: Location; SME; FT2; Kedah; Icentive; logit model. 


\section{BACKGROUND OF THE STUDY}

The importance of location for any businesses cannot be doubted. This is all the more true especially for those small-and-medium-scale enterprises (SMEs) in the manufacturing sector, which is the focus of this study. In Malaysia, it is estimated that there are approximately 20,200 manufacturing establishments, with more than $90 \%$ being SMEs. The definition for SMEs varies according to countries. In Malaysia, an SME is a company with an annual sales turnover not exceeding RM25 million or with the number of full-time employees not exceeding 150 (Malaysia, 2005).

Amidst the evolution of technology advancement in enhancing e-business, it makes one ponder on the relevancy of the role that location plays - does it make any significant contributions in influencing manufacturing SMEs' location choices in this digitally-competitive era? (1) To what extent does location factor play a role in influencing the location choices of manufacturing SMEs?

Malaysia is a land of many opportunities when it comes to doing business here, as there is never a short of incentive provisions. The provision of incentives includes those for the manufacturing, agricultural, and tourism sectors, research and development, training, and information and communication technology, just to name a few (MIDA, 2005). In

SMalaysia, the two major tax-related incentives for the manufacturing sector are the granting of pioneer status and investment tax allowance. A look at the Ninth Malaysia Plan confirms the importance that the Malaysian government places on manufacturing SMEs as the backbone -in preserving our healthy structure of economy.

By looking into the details of other incentives for the manufacturing sector, some of the incentives which are location-related include industrial estates, free industrial zones (FIZs) and licensed manufacturing warehouses (LMWs). Companies located in FIZs or companies with LMWs approvals are entitled to the exemptions of customs duty when they export their goods abroad (MIDA, 2005). These are healthy incentives especially those manufacturing SMEs planning to expand their production sales to foreign markets.

In addition to location-related incentives, there also exists a myriad of different grants ready for the perusal of eligible manufacturing SMEs. 
Most of these manufacturing-related grants, such as Business Planning and Development Grant, Product and Process Improvement Grant, Productivity and Quality Improvement Grant, Market Development Grant, and Brand Promotion Grant, are provided mostly by the Small \& Medium Industries Development Corporation (SMIDEC) and the Malaysian External Trade Development Corporation (MATRADE).

However, is the majority of the manufacturing SMEs, especially those in Kedah, utilising these incentives or even have the faintest idea about the existence of these location-related incentives? What are the priorities of manufacturing SMEs when it comes to location choices that is, how important are location incentives ${ }^{1}$ to them? Stated more specifically, it is to say how effective are the location incentives, if any, provided to the SMEs in influencing their location choice decisions. This is a similar problem statement as raised by Carod and Antolin (2004) in their industrial location study. This current study is also in line with Lindsey's study (2004) where she looked at the suitability of using tax incentives in encouraging businesses to relocate to a certain area.

How far-stretched are the effects of other factors such as non-location incentives and socio-economic influence? These are some of the research questions posed in this study. The significance and contribution of this study must not be undermined as it has been known that location decisions do have substantial effect on competition, competitive strategy, and industrial performance (McKendrick, Doner, \& Haggard, 2000).

\section{THEORETICAL BACKGROUND AND EMPIRICAL EVIDENCE}

The idea of incentives based on locations originates from location economics or location theory, thus it is worthwhile to take a look at its early thoughts. The foremost seminal work on location theory comes from Von Thunen, who is regarded as the founder of location theory (Brue, 2000, p. 242).

In general, his location theory stressed that if the products are more costly in terms of transportation, then the products will be produced closer to the market proximity and vice versa. However, Von Thunen's location theory is more concerned with agricultural products and farming location (Greenhut, 1995, p. 43). 
Recent industrial or plant location theory are based on two types of concepts, which are firstly, Weber's least-cost theory and secondly, Losch's greatest profit or alternatively known as market area theory (Miller, 1970, p. 3). A comprehensive manufacturing location theory was first developed by Alfred Weber, where based on a few assumptions, he showed how transportation cost of raw materials and labour costs influence manufacturing locations. However, Weber's least-cost theory works only in a condition of perfect competition.

In order to counter this unrealistic assumption, came along Losch's greatest profit theory which works in a condition of monopolistic competition. Generally, this theory emphasised that manufacturers will locate at a market area that can generate the highest profit. Subsequent arguments of the theory of location have been more or less, divided along these two schools of thought. Apart from the over-emphasis on transport costs in Weber's and Losch's location theories (Guimaraes, 2004, p. 1), are there any other factors that affect a firm's location decision? We will now -take a look at the more recent studies regarding the factors or incentives influencing location decisions.

Does local government fiscal policy affect business location decisions? Gabe and Bell (2004) found that businesses will choose to locate at areas where the local policies stress on large public goods and services expenditures, despite any possible increase in business tax rates. This is because business-friendly local fiscal policies lower the operating costs of a business. On the contrary, there are some areas that do rely on tax incentives to attract businesses and spur the economy's viability, as analysed by Lindsey (2004) in her study of the tax incentives policies used by the Wisconsin state in the U.S. to attract businesses to locate in that state.

Tax incentive is considered as a policy variable in the study by Loree and Guisinger (1995). In their study, they examined the effects of policy and non-policy ${ }^{2}$ variables on the location of the U.S. investment abroad. They found that tax policies, investment incentives, political stability, culture, and infrastructure levels to be significant in influencing the location decision of the U.S. investments in countries abroad. In a similar vein, Chung and Alcacer (2002) concluded that cost-minimising firms choose to locate at states with low taxes. 
In a qualitative paper by McCann and Shefer (2004), they analysed the relationship between firm location, transportation infrastructure, agglomeration economies, and regional development. They argued that the location decision is primarily determined by spatial transaction costs, which in turn are determined by the levels of transportation infrastructure - hence the importance of transportation infrastructure. Karakaya and Canel (1998) would agree to this as they found out that the transportation facilities factor is the second most important business location decisions determinant. As observed by Epping (1982), transportrelated factors have been ranked consistently high in importance. However, as found out by Buurman and Rietveld (1999), the influence of transportation infrastructure in attracting manufacturing firms to a certain area is somewhat modest, though significant. As for the more general amenities, as found out by Granger and Blomquist (1999), they too influence the location choice of SMEs, though with varying degree by industry.

A different emphasis has been stressed by Carod and Antolin (2004). They stressed that firm size is an important factor in determining the location decision of a firm. They showed empirically that larger firms are more objective in deciding their location, while smaller firms' decision is mostly based on the entrepreneurs' personal preferences and are more limited to a nearer geographical area.

There is still a myriad of important factors found to be positive and statistically significant determinants of industrial location, such as educational attainment, an existing manufacturing base, transportation infrastructure (Coughlin \& Segev, 2000), highway accessibility, industrial zone policies, agglomeration economies as measured in terms of land use, labour and population (Wu, 2000), availability and quality of labour, wage rates, labours' motivation, quality and reliability of utilities, industrial relation laws, telecommunication systems, and patent protection (MacCarthy \& Atthirawong, 2003).

Location decision-making will influence the comparative advantage of the firm. According to Townror, the location decision may involve region, community, and site factors, which may be country related (Chapman \& Walker, 1987; Townror 1976). Table 1 shows Townror's critical element in choosing the optimal location. 


\section{Table 1}

\section{Townror's Critical Elements of Locational Choice}

\begin{tabular}{lll}
\hline Key region factors & \multicolumn{1}{c}{ Key community factors } & \multicolumn{1}{c}{ Key site factors } \\
\hline $\begin{array}{l}\text { 1. Government } \\
\text { regional policy }\end{array}$ & 1. Transport and communications & 1. Intra-urban location \\
$\begin{array}{l}\text { 2. Strategic } \\
\text { communications }\end{array}$ & 2. Ties with parent plant & $\begin{array}{l}\text { 2. Physical } \\
\text { characteristics }\end{array}$ \\
$\begin{array}{l}\text { 3. Labour relations } \\
\text { market }\end{array}$ & $\begin{array}{l}\text { 3. Labour supply/cost/training } \\
\text { 4. Supply of materials and } \\
\text { components }\end{array}$ & 3. Tenure \\
& $\begin{array}{l}\text { 5. Access to services } \\
\text { buildings }\end{array}$ \\
& $\begin{array}{l}\text { 6. Local and central government } \\
\text { service }\end{array}$ & 6. Price \\
& 7. Amenities & \\
\hline
\end{tabular}

Sources. Chapman \& Walker (1987, p. 50), Asan (2006, p. 43).

"Studies on the behaviour location decision of high-tech manufacturing in North America found that high-tech manufacturing is located based on the availability of access skilled labour, founding entrepreneurs, and overall business climate in such location (Hayter, 1998). Table 2 shows the rankings of location factors by high-technology firms in four North -American surveys.

Location decisions will take into consideration the maximisation of technical efficiency. Increasing return to agglomeration of resources will make the firm in such location more productive and increasing concentration of a particular industry will cause knowledge spillovers across the firms within that specific geographic region (Lucas, 1993; Glaeser, Kallal, Scheinkman, \& Shleifer, 1992). Besides that, transport cost consideration and backward-forward linkages will increase employment growth (Hanson, 1996). Specialisation gives benefit to the local economy until the industry growth begins to decline, after that the high level of specialisation level will become a liability to the local economy rather than an asset (Temple, 1996). 


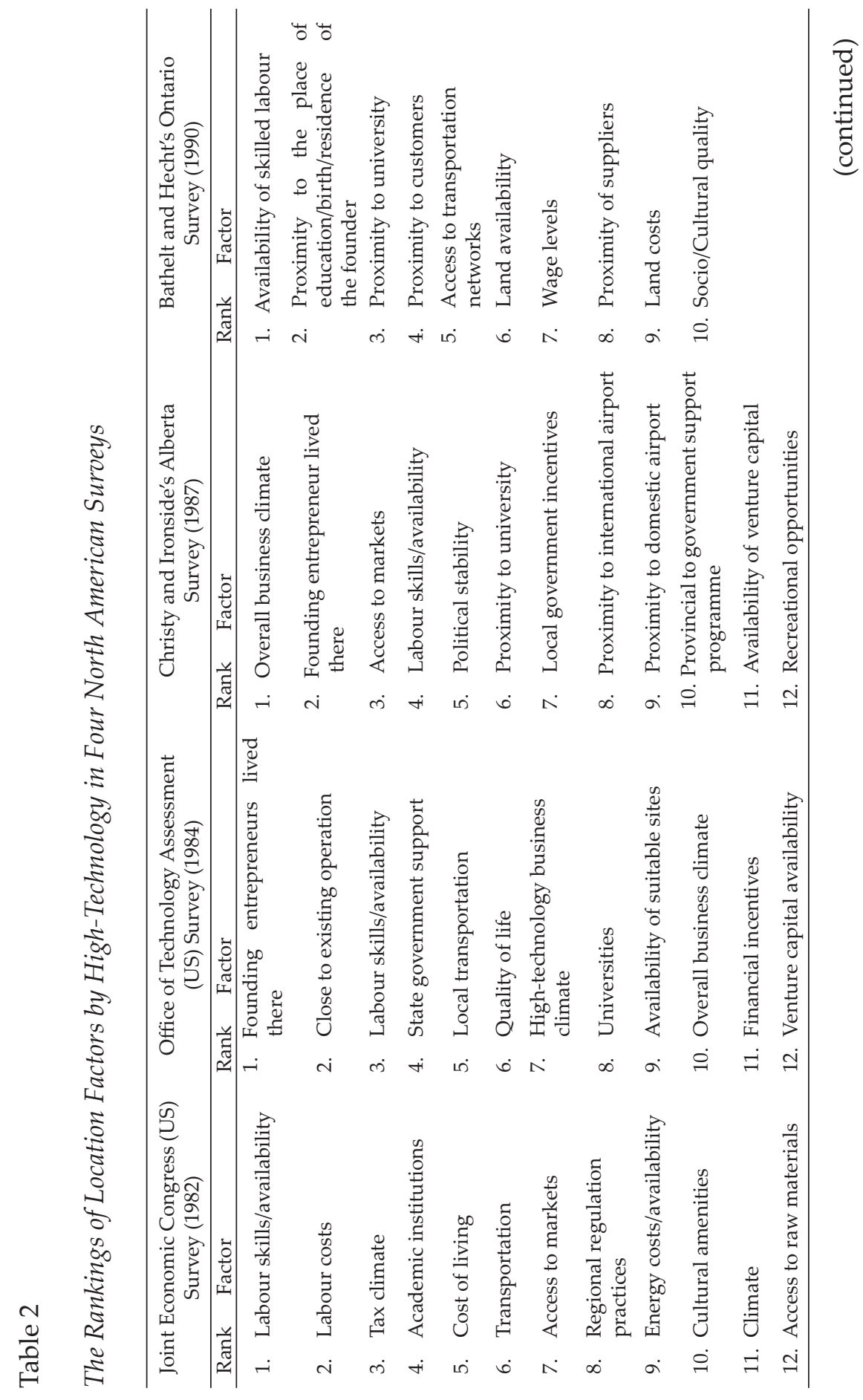




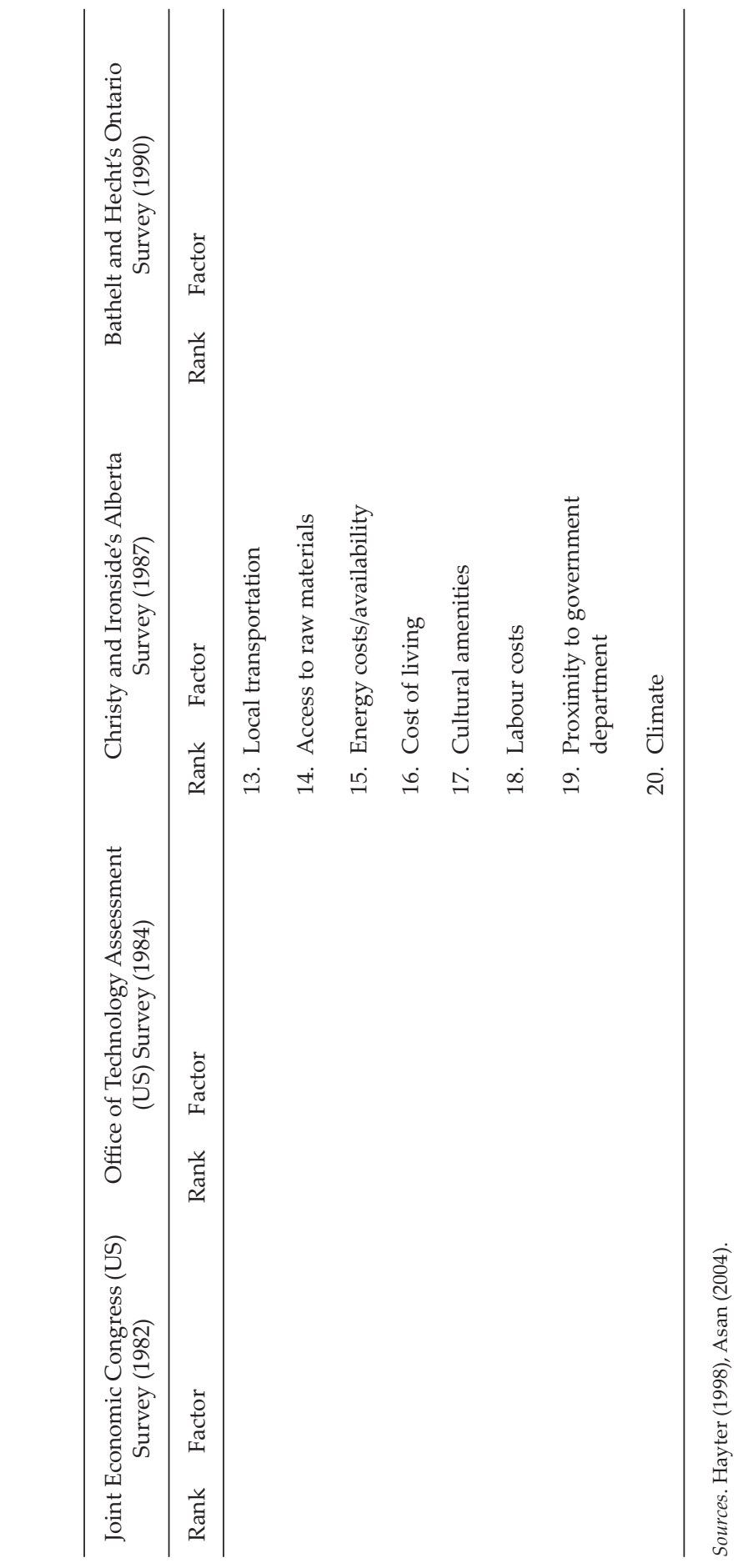

130 IJMS 16 (2), 123-153 (2009) 
It is quite possible to identify a standard optimum location because different groups of industry, geographic location, culture, economic system, and government policy will influence decision-making. Comparative advantage and increasing return will depend on degree of internal and external economies or dis-economies on agglomeration, specialisation, localization, and urbanisation. In many cases, government intervention in regional policy will affect the location decision, especially by multinational entrepreneurs (Asan, 2004, p. 46).

In order to promote industrial activities in the less developed states (or districts), the government introduced the concept of a "development area" under the Investment Incentive Act 1968. Industries located in these areas would be granted with additional incentives. There development areas cover the entire states of Perlis, Terengganu, Malacca, Sabah, Sarawak, and the relatively less developed districts of Kedah (excluding Kuala Muda district), Pahang (excluding Kuantan district), and southeast of Johor (Figure 1). It also includes two industrial estates; Kemunting Industrial Estate (in the state of Perak) and Senawang Industrial Estate (in the state of Negeri Sembilan); and two Free Trade Zones (FTZ) industrial areas, namely Bayan Lepas FTZ (in the state of Pulau Pinang) and Sungei Way FTZ (in the state of Selangor). These two industrial areas form the pioneer industrial areas and are isolated from concentrated industrial areas in the state of Selangor and Pulau Pinang while, the FTZs are the pioneer FTZ in Malaysia ${ }^{3}$.

After the implementation of the NEP, the government introduced the 'Location Incentive Scheme' (under the Investment Incentive Act 1972). More incentives were given to the local and foreign investors to locate their activities in the less developed states (or districts) ${ }^{4}$, mainly to redistribute the industrial activities from more concentrated areas in the more developed states. Compared with the development area under the Investment Incentive Act 1968, the Location Incentive Act 1972 only coveres the entire states of Perlis, Terengganu, Malacca, Sabah, Sarawak, and the relatively less developed districts of Kedah (excluding Kuala Muda district), Pahang (excluding Kuantan district), and southeast of Johor. It does not include Kemunting Industrial Estate, Senawang Industrial Estate, Bayan Lepas FTZ, and Sungei Way FTZ, because it refers only to the less developed states (or districts).

Further incentive was given under the Promotion of Investments Act 1986, which was introduced as a replacement for the Investment Incentive Act 1972. Although industrial development focused more on the WestCoast corridor, additional incentives were given to the industries located in the East-Coast corridor of Peninsular Malaysia. It covers Kelantan, Terengganu, Pahang and the district of Mersing in southeast of Johor. 


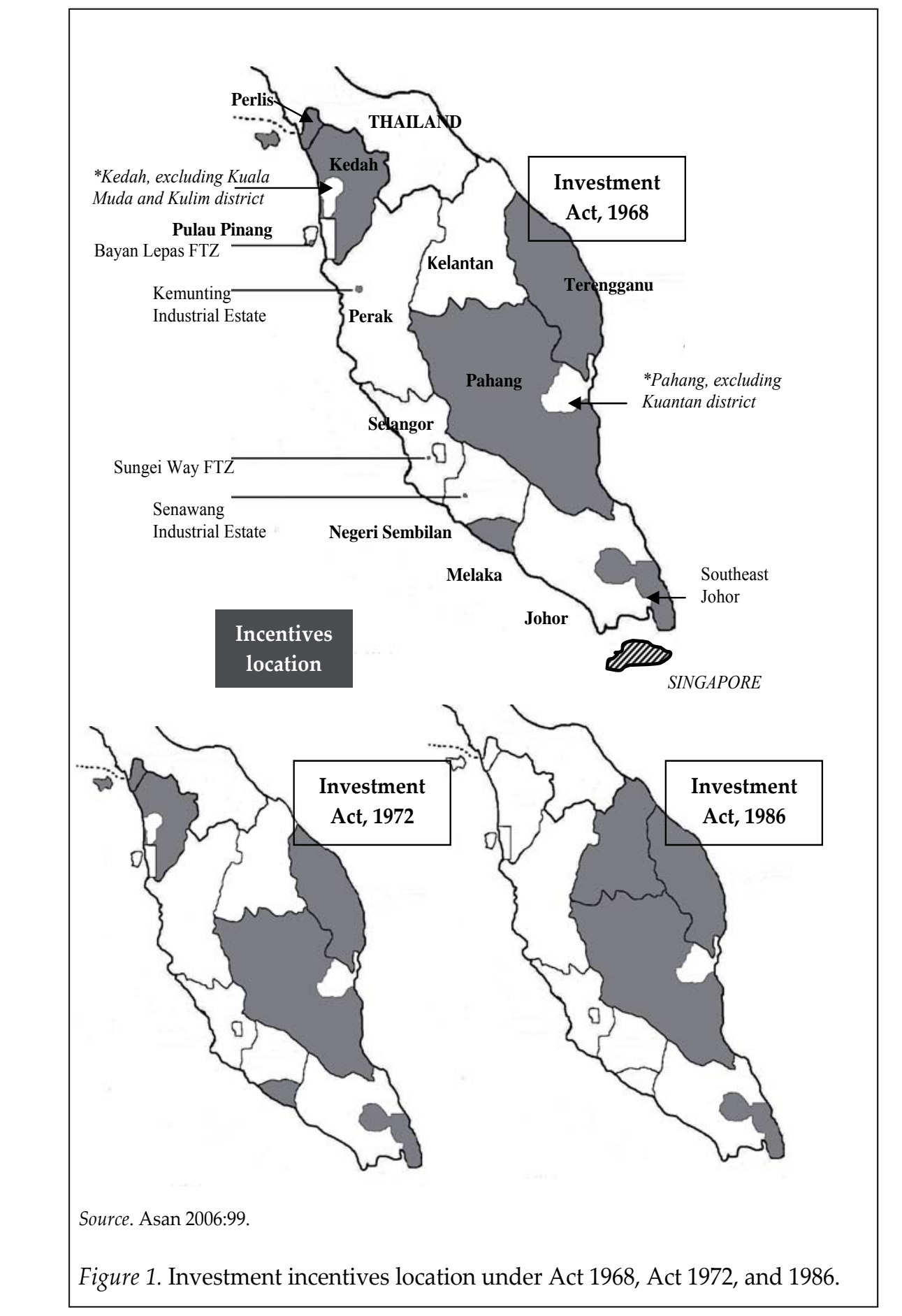

132 IJMS 16 (2), 123-153 (2009) 
Compared with the 'Location Incentive Scheme' (under the Investment Incentive Act 1972), additional incentives under the Promotion of Investments Act 1986 did not cover the states of Malacca, Kedah, and Perlis (located in the West-Coast of Peninsular Malaysia) because the additional incentives were only given to the industries located in the East-Coast corridor of Peninsular Malaysia, mainly to give it more of a comparative advantage ${ }^{5}$. The manufacturing activities in these states were relatively less and the economic sector still depended on the agricultural sector, which recorded lower monthly incomes, and higher level of poverty and unemployment, as well as out-migration.

The Investment Incentive Act was replaced for two reasons, firstly to make investment in Malaysia more attractive and to have extra competitive advantage compared with other countries in the ASEAN region. This is because other countries also have their investment incentives and Malaysia has to compete to attract the FDI, especially from multinational companies. Secondly, regarding the additional incentives given to the selective states or districts, the number of states that receive the incentive was decreased from six states under the Investment Act 1972, to only three states under the Investment Act 1986. Kedah, Perlis, and Malacca, that were given additional incentives under the Investment Act 1972, no longer received additional incentives under the Investment Act 1986. Manufacturing activities in these states increased rapidly, and focus had to be given only to the states located in the East-Coast corridor (Kelantan, Terengganu, and Pahang), where the manufacturing activities were relatively less.

Besides incentives under the Investment Incentive Act, since 1971, the State Economic Development Council (SEDC) also provided some incentives to promote investors, especially FDI, to set-up factories in those particular states. All these incentives provided under the Investment Incentive Act (Federal government) and under the State Economic Development Council (state government) can be summarised in Table 3.

Besides the huge incentives in manufacturing industries especially in the less developed states, the government also took further steps to promote manufacturing industries by developing industrial estates. This strategy seeks to encourage new manufacturing industries to move to the less developed parts of the country, especially in the east-coast states from the congested areas in Selangor (Klang Valley) and other major urban centres in the west coast. 


\section{Table 3}

\section{Incentives Provided Under the Investment Incentive Act and Under State Economic Development Council}

$\begin{array}{cc}\text { Incentive under } & \text { Incentive under State Economic } \\ \text { Investment } & \text { Development Council } \\ \text { Incentive Act } & \end{array}$

\begin{tabular}{l}
\hline \\
State/
\end{tabular}

excluding Kuala Muda and Kulim Districts.

industrial estates of Kamunting only.

${ }^{3}$ excluding Kuantan district (other than Gobeng Industries Area and Bentong District).

industrial estates of Senawang only.

southeast (Mersing district) of Johor only.

Bumiputera investors in the state of Kedah are provided a discount of $5 \%$ on purchases of industrial land and ready built workshops/factories.

The Perak State Economic Development Council (SEDC) has lowered the assessment rates for factory sites within Ipoh City from $16 \%$ to $10 \%$ and provides a $30 \%$ reduction in the land premium.

c Investors in Melaka are allowed to purchase industrial land through an extended payment scheme over a period of 5 to 10 years. Industrial land in industrial estates in Melaka enjoy concessionary quit rent and water rates. Melaka also gives a discount of $7 \%$ on all payments made within 6 months from the date of offer; a further $3 \%$ is given on completion of factories within 12 months from the same date.

d Kelantan's instalment plan is $10 \%$ payable on signing of agreement, $10 \%$ one month later, $30 \%$ two months later, $50 \%$ payable within three months of signing of agreement. Kelantan's rental rate for ready built factories allow discount based on number of workers and floor space.

(continued) 
e Terengganu SEDC operates a Special Incentives Scheme. Under this scheme, investors creating total employment for more than 200 workess obtain industrial land prices at M\$0.50 per square metre to a maximum of 4 hectares and a $50 \%$ lowering in the annual assessment rate. Quit rent is also negotiable.

f Pahang SEDC operates a progressive payment scheme with the $20 \%$ down payment into two instalments of $10 \%$ each with a grace period of 6 months. Investors are given a grace period of 6 and 9 months after the first and second down payment respectively and the balance is paid in 4 instalments equally distributed over the next 9 - month period. Quit rent for industrial lands lowered by $50 \%$ to $15 \%$ per 100 metres for the first two hectares.

Sources. Asan (2004, p. 158); Asan (2006, p. 101).

States that recorded a huge decrease in their output and labour contribution to the Malaysian total were Selangor and Perak, while states that recorded a big increase in output and labour contribution to the Malaysian total were Pulau Pinang (7.4\%) and Johor (5.1). This situation showed that several incentives under the federal and state governments were not successful in their goal to increase manufacturing activities in the less developed states. Pulau Pinang and Johor were not placed under any status of Development Area or under Location Incentive Scheme, as well as East-Coast Corridor or any other incentives under SEDC, but the manufacturing output and labour contribution was increasing and still relatively high. Although the district of Mersing (in southeast Johor) was placed under the status Development Area and under Location Incentive Scheme, and currently under the East-Coast Corridor, only contributed less than two percent to total manufacturing output and labour (Asan, 2006, p. 103) $)^{6}$.

An investment incentive plays an important role in increasing manufacturing activities in Malaysia. Investment incentives in Malaysia started with the Investment Incentive Act 1968, which was replaced by the Investment Incentive Act 1972. Further incentives were given under the promotion of Investments Incentive Act 1986, which was introduced as a replacement for the Investment Incentive Act 1972. Most apparent effect from the government industrial incentive is in terms of Investment Incentive Act 1986. Before the 1986 Act, about 37 to 47\% of approved projects were the result of investment incentives given by the government. This amount increased rapidly after the 1986 Act, for instance, in 1990, the amount increased to about 58\%. However, it decreased in 1997 due to the economic downturn. Most of the industries that received this incentive were the export-oriented industries located in the more developed states, especially in Selangor, Pulau Pinang, and Johor. Location incentives were less effective; projects approved under this incentive were small compared to other incentives since it only accounts for less than three percent of the approved manufacturing projects with incentives (Asan, 2006, p. 104). 
Growth in the manufacturing sector since the 1980s was a result of the diversification of manufacturing toward a capital-intensive industry, especially export goods, as well as maximisation of the comparative advantage of Malaysia's resource endowment. Specific tax incentives were also provided to encourage the growth of export-oriented industries. Besides this, a substantial proportion of manufactured exports came from the FTZs ${ }^{7}$. FTZs are specially designated for exportoriented industries. There have been 14 FTZs in Malaysia, 11 of the FTZs were located in the more developed states and the rest were in the less developed states (Kedah, Kelantan, and Pahang). Infrastructure network, which provided easy access to the service industry, was the main reason why most of the FTZs were located in the more developed states. The FTZs were developed near the well-established industrial estates and -infrastructure network mainly to enable them to generate backward and forward linkages to other industries, as well as to make it more attractive for the FDI (Asan, 2006, p. 107).

Doverall industrial concentration showed more dispersal for food, -beverages, and tobacco and basic metals, wood and products, chemicals and rubber industries, and non-metallic minerals in the year 1995. At the same time, industries such as textiles and clothing, paper and printing, metal product, and machinery remained concentrated in the more developed states. Although the concentration of those industries was on an increase in the less developed states, the concentration of capital, labour, value, and output remained dominant in the more developed states. This scenario has close links with the background of the labour market in that particular state. It is undeniable that an educated and experienced worker would migrate to the more developed states and the inexperienced ones would remain in the less developed states. -This creates a lower technological industrial environment in the less developed states giving rise to such industries such as food processing, drinks, furniture, paper products, rubber products, and non-metal products. These industries are not only providing lower labour product ability, but also lower wages (Asan, 2006, p. 107).

Since the 1970s, the public and private sectors have experienced rapid growth. Both sectors have played an important role in meeting the development objectives of the nation as well as achieving the New Economic Policy (NEP) objectives of poverty eradication and societal restructuring. At the beginning of the NEP, the public sector paid more attention to increasing public utilities (physical infrastructure and other social infrastructure) and to increasing the quality of life in rural 
areas. Private investment expanded rapidly in the industrial sectors, particularly in manufacturing and construction, petroleum exploration and production, and in the export-oriented industries located in the FTZs.

The FDI increment was higher in the more developed states. In terms of percentage output share, chemical products were important in Johor, while electrical, electronics, and machinery products were important in Melaka, Negeri Sembilan, Perak, Johor, and especially in Selangor and Pulau Pinang. Kedah was the only less developed state that had the advantage of increasing FDI in electrical, electronics, and machinery products. Kedah experienced the spread effect because it is located near the northern regional growth centre. The state of Kedah also has the advantage of external diseconomies of urbanisation in Pulau Pinang (potential for congestion, high wages, and high employee turnover). FDI firms were more geographically dispersed throughout the Peninsular Malaysia as compared with local investment firms while, local investors were more concentrated in Selangor, Johor, and Terengganu. This situation somehow contradicts the early hypothesis of this study that FDI would increase the inequality between states in Peninsular Malaysia (Asan, 2006, p. 109).

\section{DESIGN OF THE STUDY}

\section{Objectives of the Study}

The objectives of this paper are to look at how location incentives influence the location choice of the SMEs in the Kedah state and also to find out what other factors that matters most to them in the time when they made their location choice decisions. The following section takes a look at the literature of location-related studies, followed by the methodology section. The subsequent section discusses the analyses and results, followed by a final section on conclusions, policy implications, and recommendations.

\section{Information Sources}

The data comprises 330 registered manufacturing SMEs in Kedah. It was collected using a questionnaire survey with a cluster sampling method. The survey was carried out from March to April 2006 through out Kedah. Among 330 questionnaires that were distributed, 99 are returned. This 
approximates to a 30\% response rate. However, out of these 99 sets of questionnaires, only 77 sets were usable.

The questionnaire was categorised into three major parts. Part A consists of company profile questions, part B relates the different types of incentives with location choice, while the rest of the questionnaire contains questions that deal with financial products and ICT used by SMEs, human resource, production, accessibility of finance, and the difficulties faced by SMEs.

The control variables of this fraction are the number of workers hired by respondent firms, age of companies, location incentive factor and non-location incentive factors, the ownership structures, distribution of -products, and types of grants received are the independent variables that were utilised in this study. They were selected based on past studies.

\section{Research Technique}

-A dichotomous logit model was used in this study. The simple logit model that adopted in this study is as follows:

$$
\begin{aligned}
\log \left(\frac{P}{1-P}\right)_{i}= & \beta_{0}+\beta_{1} X_{1 i}+\beta_{2} X_{2 i}+\beta_{3} X_{3 i}+\beta_{4} X_{4 i}+\beta_{5} X_{5 i}+\beta_{6} X_{6 i} \\
& +\beta_{7} X_{7 i}+\beta_{8} X_{8 i}+\beta_{9} X_{9 i}+\beta_{10} X_{10 i}+\beta_{11} X_{11 i}+\mu_{i}
\end{aligned}
$$

where,

P is the probability of choosing Sungai Petani (SP),

-Dependent variable LOCATION= 1 if choose SP,

$=0$ otherwise,

$\mathrm{X}_{1}-\mathrm{X}_{11}$ are the independent variables, and

$\mu_{\mathrm{I}}$ is the white noise error term.

$\mathrm{X}_{1}-\mathrm{X}_{6}$ are the dummy variables that represent location choice factors (availability of raw material, availability of labour, infrastructure facilities/ near to port, industrial cluster, security, free trade zone/accessibility, and other factors), with location incentive as the comparison group. They are factors that influence the location choice made by the respondent firms (self-perceived). 
$X_{7}$ is the number of workers, $X_{8}$ represents age of SMEs (in years), $X_{9}$ is the ownership structure ( 1 being bumiputra and 0 otherwise), $X_{10}$ is distribution of products ( 1 for local market and 0 otherwise), and $X_{11}$ represents the grants received by SMEs ( 1 if received and 0 otherwise).

\section{Limitations of Study}

There are some limitations in this study as the sample size was quite small, covering just the SMEs in Kedah. However, this study is significant because these SMEs are the ones who create most of the manufacturing jobs in Kedah. This is in line with the Kedah vision to be a developed state by year 2020. In future research evolving from similar topics, they can generalise their findings of a larger sample to include other states of Malaysia.

Although we are well aware that the most popular and principal method of analysing industrial location decisions (Carod \& Antolin, 2004; Guimaraes et al., 2004) is by using the conditional logit model, we chose to undertake the current methodology, which is the logit model. However, based on the data that we collected, the areas of Kuala Ketil, Jitra, Gurun, and Alor Setar had low observations. This low number of observations has lead to an estimation problem in the multinomial logit model. The estimation problem also occurs even in the case of three categories (1 for Sungai Petani, 2 for Kulim, and 3 for Kuala Ketil/Jitra/ Gurun/Alor Setar, as shown in Appendix 1). So we regrouped our data into two groups. In this case, the logit model is more suitable as it is a dichotomous model. Indeeed, as shown by the data, Sungai Petani (SP) is the most popular choice. Hence, it is of interest to find out factors that determine between location choice of SP and non-SP.

The location choice factors (variables $\mathrm{X}_{1}-\mathrm{X}_{6}$ ) appear to be alternativespecific variables. Nevertheless, information about location choice factors is available only for one of the location choices (that has been made by the SME - Sungai Petani or Non-Sungai Petani). For instance, respondent 1 perceived that "availability of labour" is the factor (compared to other factors including location incentives) that made him/her choose to locate his/her SME in Sungai Petani. For this respondent 1, information related to location choice factors is not available on other location choice (NonSungai Petani, such as Kulim, Alor Setar, and others). Hence, we were not able to estimate the conditional logit model. 


\section{DISCUSSION AND ANALYSIS}

\section{Discussion on Descriptive Statistics}

The logit model was used to study the location choice decision of firms located in six industrial areas in Kedah. The said areas were Sungai Petani, Kulim, Alor Setar, Jitra, Kuala Ketil, and Gurun. A total of 330 sets of questionnaires were distributed in these areas, but only 99 were returned. Among these 99 sets of questionnaires, 77 sets met the definition of SMEs set by SMIDEC. SMEs are defined differently according to individual country and sector of industry. In Malaysia, for the manufacturing sector, SMEs are companies that have not more than 150 full-time workers or an annual sales turnover of less than RM25 million. Consequently, 22 sets of questionnaires which have more than 150 workers were excluded from this study.

(1) This represents a response rate of $23.33 \%$. The poor response rate is -mainly due to the lack of cooperation from the firms. Out of these 77 sets, the majority of respondent firms are from Sungai Petani. They make up of $68.8 \%$ of the total. This is followed by Kulim, which constituted 15 respondents (19.5\%). The response rate of Alor Setar is less than onetenth (6.5\%) while Gurun has 1\% more than Jitra and Kuala Ketil. These areas have the lowest returned rate. Their response rates are at 1.3\% respectively (Table 4).

Table 4

The Distribution of Respondent Firms According to Industrial Areas

Area

Sungai Petani

Kulim

Alor Setar

Gurun

Kuala Ketil

Jitra

Total

Frequency

53

15

5

2

1

1
Percentage (\%)

68.8

19.5

6.5

2.6

1.3

1.3 
Sungai Petani encompasses the highest number of workers, which is over 2000. In contrast to Sungai Petani, Jitra has the lowest number of workers, Whereas Kulim has less than 1000 employees. The number of workers for Kulim fall in the range of 20 to 140. Although Alor Setar and Gurun have quite similar numbers of employees, the distributions of the workers in at the disaggregate level are totally different. The amount of employees in Alor Setar is in the range of 20 to 40, whilst the workers in Gurun are at least one fold higher than Alor Setar (40 to 100). Kuala Ketil and Jitra again have not shown any significant changes in the distribution of employees. The number of employees in Kuala Ketil is slightly higher than Jitra, approximately 40.

A vast number of factors, such as availability of labour, raw material, accessibility, security, and government incentives, is believed to have influence on location choice. In this study, we are interested in investigating the impact of location incentive on location choice made by respondent firms. Therefore, we compared the differential impact of location incentive to other non-location incentive factors. Around $80 \%$ of the location choices are induced by non-location incentives. Indirectly, it means that only one-fifth $(20.8 \%)$ of the decisions are affected by location incentive.

Table 5

Factors that Influence Location Choice

\begin{tabular}{|c|c|c|}
\hline & Frequency & Percentage $(\%)$ \\
\hline Location incentive & 16 & 20.8 \\
\hline Availability of raw material & 6 & 7.8 \\
\hline Availability of labour & 9 & 11.7 \\
\hline Infrastructure facilities/near to port & 12 & 15.6 \\
\hline Industrial cluster & 17 & 22.1 \\
\hline Security & 2 & 2.6 \\
\hline Free trade zone/accessibility/others & 15 & 19.4 \\
\hline Total & 77 & 100 \\
\hline
\end{tabular}

This study indicated that over half $(57.1 \%)$ of the respondents did not receive any grants. About one-third (37.7\%) of the respondents obtained one grant only. The grants obtained are Product and Process Development Grant, Business Planning, and Development Grant, and other grants such as Rossettanet and Marketing Development Grant. In this study, there was roughly $5 \%$ (4) of respondents that were unwilling to answer this question. 


\section{Table 6}

The Total and Percentage of Grant Received by Respondents

\begin{tabular}{lcc}
\hline & Frequency & Percentage (\%) \\
\hline Received & 29 & 37.7 \\
did not receive & 44 & 57.1 \\
Missing Values & 4 & 5.2 \\
\hline Total & 77 & 100 \\
\hline
\end{tabular}

\section{Discussion on Empirical Findings}

This section presents the empirical findings from our study. Table 7 posits the results of the Binary Logit Model. To measure the overall significance of the model or in another words, the goodness-of-fit of the - logistic regression that was used, the Likelihood Ratio Statistic test (LR statistic) was computed. It was found that the p-value of LR statistic is almost zero (0.0003). A p-value of less than 0.05 implies significance, which is to say that the logistic model that was used has a good fit $(\mathrm{Wu}$, 2000). Thus, it can be concluded that overall, the estimated model is statistically significant. It also means that the joint null hypothesis of all slope coefficients being zero is rejected. Besides the LR statistic, the computed McFadden R-squared is reported as 0.4056. Since this figure is greater than 0.2 , it signifies that a very good fit model was used $(\mathrm{Wu}$ \& Strange, 2000).

"In this study, our dependent variable is the logarithm of the odds that an individual firm makes certain location choice. Each individual firm has only two options of location choices, namely "Sungai Petani" and "non Sungai Petani". Non-Sungai Petani represents the choice made on other areas excluding the Sungai Petani Industrial Area. Choice made on Sungai Petani is called Event A and it is quantified as 1. Choice made on other areas is defined as Event B and this is represented by 0. Event A is selected as a baseline for comparison with the choices of other areas.

There were six industrial areas involved in this study, but only two categories of location choice was choice. The description of the data showed that Sungai Petani is the most popular choice. However, the other locations, such as Kuala Ketil (1), Jitra (1), Alor Setar (5), and 
Gurun (2), have very low observations. Therefore regions were grouped together, thus two groups were formed, namely Sungai Petani and nonSungai Petani, which were used in the model.

\section{Table 7}

The Empirical Results of Binary Logit Model

\begin{tabular}{|c|c|c|c|}
\hline Variable & Coefficient & $\begin{array}{l}\text { Odds } \\
\text { ratio }\end{array}$ & $\begin{array}{c}\text { Marginal } \\
\text { effect }\end{array}$ \\
\hline \multicolumn{4}{|l|}{ Location choice factors: ${ }^{1,3}$} \\
\hline F_raw_mat & $\begin{array}{l}-0.2325 \\
(1.8329)\end{array}$ & $\begin{array}{c}0.7926 \\
(1.4527)\end{array}$ & $\begin{array}{l}-0.0244 \\
(0.2078)\end{array}$ \\
\hline F_labour & $\begin{array}{l}-1.3406 \\
(1.2909)\end{array}$ & $\begin{array}{c}0.2617 \\
(0.3378)\end{array}$ & $\begin{array}{l}-0.1897 \\
(0.2370)\end{array}$ \\
\hline F_infra1 & $\begin{array}{c}0.3105 \\
(1.3078)\end{array}$ & $\begin{array}{c}1.3641 \\
(1.7839)\end{array}$ & $\begin{array}{c}0.0279 \\
(0.1086)\end{array}$ \\
\hline F_ind_clu & $\begin{array}{l}-0.6040 \\
(1.1973)\end{array}$ & $\begin{array}{c}0.5466 \\
(0.6545)\end{array}$ & $\begin{array}{l}-0.0671 \\
(0.1483)\end{array}$ \\
\hline F_security & $\begin{array}{l}-3.1790 \\
(2.2573)\end{array}$ & $\begin{array}{c}0.0416 \\
(0.0940)\end{array}$ & $\begin{array}{l}-0.6285 \\
(0.4236)\end{array}$ \\
\hline F_others1 & $\begin{array}{l}-1.0813 \\
(1.4225)\end{array}$ & $\begin{array}{c}0.3391 \\
(0.4824)\end{array}$ & $\begin{array}{l}-0.1418 \\
(0.2353)\end{array}$ \\
\hline \multicolumn{4}{|l|}{ Other variables } \\
\hline Workers & $\begin{array}{l}-0.0092 \\
(0.0118)\end{array}$ & $\begin{array}{c}0.9908 \\
(0.0117)\end{array}$ & $\begin{array}{l}-0.0009 \\
(0.0012)\end{array}$ \\
\hline Age & $\begin{array}{l}-0.3295 \\
(0.0970)^{* * *}\end{array}$ & $\begin{array}{l}0.7193 \\
(0.0698)^{* * * *}\end{array}$ & $\begin{array}{l}-0.0320 \\
(0.0107)^{* * * *}\end{array}$ \\
\hline Ownership & $\begin{array}{c}0.7298 \\
(1.0705)\end{array}$ & $\begin{array}{c}2.0746 \\
(2.2209)\end{array}$ & $\begin{array}{c}0.0585 \\
(0.0714)\end{array}$ \\
\hline Distribution & $\begin{array}{c}3.3560 \\
(1.4856)^{* *}\end{array}$ & $\begin{array}{c}28.6748 \\
(42.5981)^{* *}\end{array}$ & $\begin{array}{l}0.2346 \\
(0.0831)^{* *}\end{array}$ \\
\hline Grants & $\begin{array}{l}-0.9424 \\
(0.8135)\end{array}$ & $\begin{array}{c}0.3897 \\
(0.3170)\end{array}$ & $\begin{array}{l}-0.0997 \\
(0.0967)\end{array}$ \\
\hline _cons & $\begin{array}{l}5.9306 \\
(1.7400)^{* * *}\end{array}$ & - & - \\
\hline
\end{tabular}

Note.

1. Comparison group: Location incentive.

2. $\quad * * *$ and ${ }^{* *}$ represent significance at $1 \%$ and $5 \%$ levels, respectively.

3. Values in parenthesis: estimated standard error.

4. F_RAW_MAT: availability of raw material; F_LABOUR:availability of labour; F_INFRA1: infrastructure facilities/near to port; F_IND_CLU:industrial cluster; F_SECURITY: security; F_OTHERS1: free trade zone/accessibility/other factors. 
The number of workers hired by respondent firms, age of companies, location choice factors, the ownership structures, distribution of products, and types of grants received are the independent variables utilised in this study. They were selected based on the past studies.

As shown in Table 7, we can interpret the coefficient directly. For instance, we may interpret the slope of the number of workers as when the number of worker increase by 1 , the log of the odds (or the log-odds) in favouring Sungai Petani decreases by 0.009 , ceteris paribus. However, such interpretation is less interesting and useful in the Logit Model. It is believed that the interpretation would be more meaningful if we took the antilog of the coefficient and get the odds ratio, and compute the marginal effect on probability of choosing Sungai Petani. So, Table 7 (columns 3 and 4) shows the value of odds ratio of each coefficient and the marginal effect.

For the number of workers, which is a discrete variable, we found that this variable is insignificant at $5 \%$. This means that as the size of workers "grow, the firm tends to choose other industrial areas such that an increase of one worker will reduce the probability of choosing Sungai Petani by $-0.09 \%$ (as shown by the estimated marginal effect). This may be true since the size of land that has been allocated for the Sungai Petani Industrial Area is more suitable for small and medium sized factories. An increase in the amount of workers means more space and an expansion of the factory are needed if shift production is not practised by the firm. The firm may need some time to enlarge its factory.

The need for a firm to expand its existing production base in Sungai Petani does not mean that they can do just that, because they have to "compete for land usage with residential users (Guimaraes et al., 2004). At the same time, renovation work may also affect the productivity of the production. In this case, the cost of renovation and expansion may be higher than moving to a new building at a new industrial area which may enable firms to enjoy more benefits. Furthermore, the industrial land in Sungai Petani is already packed with SMEs which have mushroomed over the last two decades and no immediate plans of expanding the Sungai Petani industrial land are in sight.

In contrast with the worker variable, the number of years in operation or also known as the economic life of a plant (Epping, 1982), was also included in this model. In this current study, we refer to it as the age of the SMEs. This variable is reported to have significant impact on 
location choice at the $1 \%$ level. The estimated results suggested that as the age increases by one year, the probability of choosing Sungai Petani decreases by $3.2 \%$, while holding other variables constant. This implies that as age increases, the respondent firm may be at the mature stage and thus it has more ability to open other branches or diversify the scope of business at other locations to cater for a more extensive market in different geographical areas, rather than moving.

The dummy variables of location choice factors were included in the model to test the impact of location incentive and other location factors on SME's location choice. Compared to location incentive, all the other location choice factors, except infrastructure facilities/near to port, have negative marginal effects. This indicates that the probability of choosing Sungai Petani is higher for location with incentive, as perceived by the SMEs, ceteris paribus. However, these non-location incentive factor variables were found to have less significant impact on location choice. Perhaps this may suggest that there are other non-location incentives that play more important roles in affecting the location choice decision. This finding supports the location choice theory saying that location incentive is not as important as per se. This has been proven by Gabe and Bell (2004), where they concluded that tax cuts in an area may actually attract fewer businesses. Their findings are also similar with the result of our survey which showed that out of 77 respondent firms, only onefifth of them ranked location incentive as the key factor in influencing location choice.

From Table 7, the distribution dummy variable (where 1 stands for products are distributed locally and 0 for not distributed in the local market) is reported to have a significant impact on probability of choosing Sungai Petani. For those products that supply to the local market, their probability of choosing Sungai Petani is $23.46 \%$ higher than those sold for non-local market. This finding reflects the real situation, because as compared to other areas, Sungai Petani is more accessible and has a higher population. Its strategic location enables it to supply products economically to not only Kedah, but also Penang. However, it is not located near a port, as compared to Kulim, so it is not surprising that those that sell goods to the local market tend to choose Sungai Petani over non-Sungai Petani locations.

For the grant dummy variable, where 1 indicates the acquisition of grants and 0 means the respondent firm does not receive any grant, it has a p-value that is larger than 0.05 . So statistically, the acquisition of 
grants was a found to be less important in affecting the location choice. This may be due to the reason that no matter where an SME is situated, be it at Sungai Petani or otherwise, the SME is still eligible to apply for such grants. Also, from the descriptive statistics, one can notice that the SMEs are unevenly distributed, with a majority of SMEs located in Sungai Petani. According to Krugman, as quoted by McCann and Shefer (2004), these uneven distribution of industries can be viewed as a natural result of market process with the workings of agglomeration economics in play. The marginal effects of -0.0997 may be explained as; for an in acquisition of grant, the probability of choosing Sungai Petani decreases by $9.97 \%$ as compared to non-acquisition of grants, with other factors remaining unchanged.

The main findings in this study indicated that destination of distribution of products have a positive impact on the probability of selecting Sungai Petani as an activity location as compared to non-Sungai Petani areas, but age of company has the inverse effect on location choice.

To gain further insights on the impact of age, distribution, and location choice factors on the probability of choosing Sungai Petani (and nonSungai Petani), these probabilities were estimated based on different -values of these variables (age, distribution, and location choice factors), while holding other variables at their mean values, respectively. These estimated probabilities are graphed for ease of interpretation.

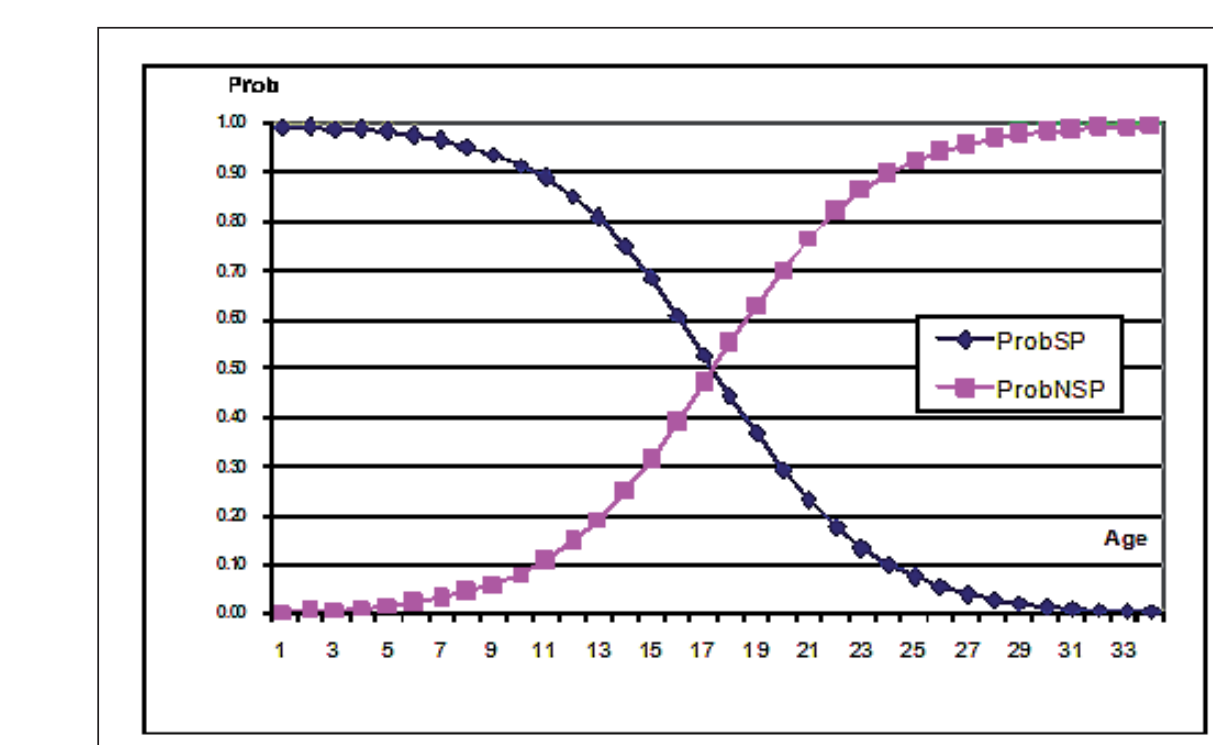

Figure 2. Age and its impact on probability of choosing Sungai Petani. 
Figure 2 clearly illustrates the non-linear and negative impact of a company's age on the probability of choosing Sungai Petani. For companies aged from one to ten years, it is almost certain that they will choose Sungai Petani (more than 90\% chance); whereas, companies aged more than 24 years, it is almost certain that they will not choose Sungai Petani (more than $90 \%$ chance). Figure 3 shows the effect of distribution - firms who sell their products to local market or non-local market are very likely to choose Sungai Petani. This indicates popularity of Sungai Petani for SMEs. However, relatively, those who sell to local market are more likely to choose Sungai Petani than those who sell to non-local market.

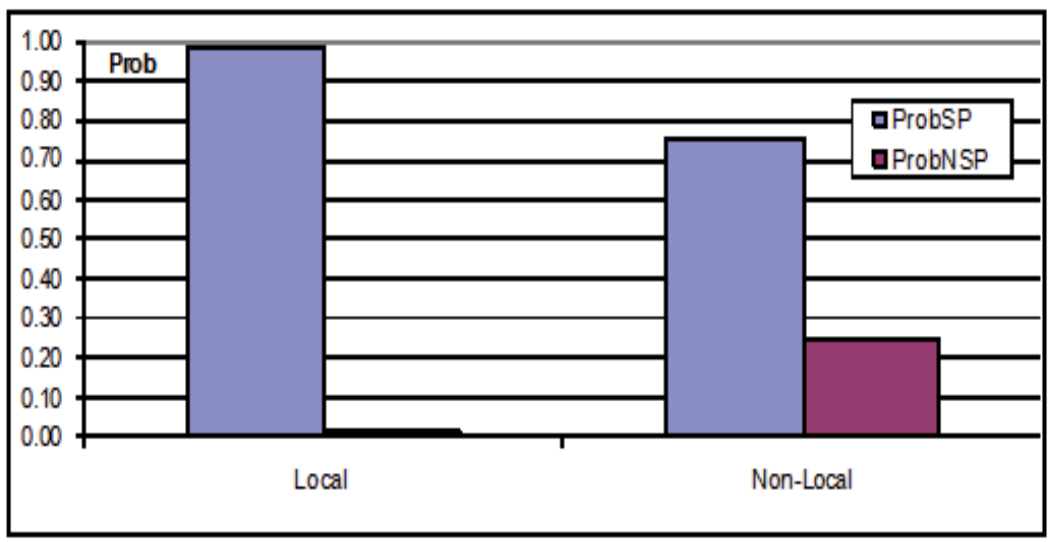

Figure 3. Distribution and its impact on probability of choosing Sungai Petani.

Figure 4 presents the effects of location choice factors - in terms of location incentive factor (Loc Incentive) versus other other location choice factors. From Figure 4, it indicates that there are no substantial differences between the location incentive and non-location incentive factors (except security factor). Those who perceived location incentive as an important factor, they have no significant differences (in their probability of choosing Sungai Petani) from those who perceived other non-location incentive factors being more important. All of them (except those that perceived security as an important factor) have high probability of choosing Sungai Petani. 


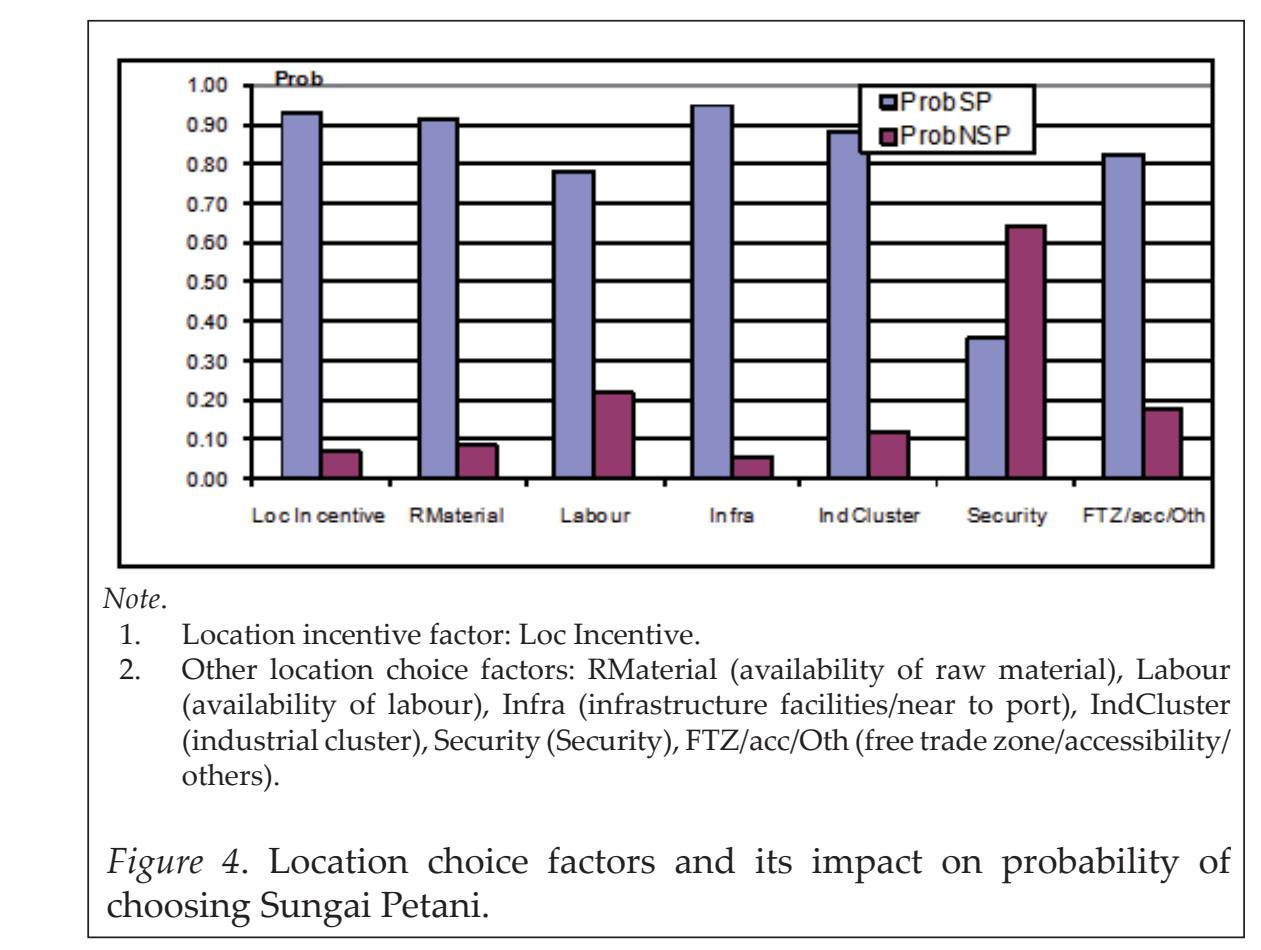

\section{CONCLUSIONS AND POLICY IMPLICATIONS}

There are a few main findings from this study. The first one was that location incentive appears to be insignificant in influencing location Choice. Two explanatory variables were reported to have significant impact on location choice. They are age of SMEs and distribution of product. Whereas the number of workers and acquisition of grants by SMEs were found to have insignificant influence.

Based on our results, some suggestions on possible policy implications are noted. Location incentive is no longer the sole factor in affecting location choice. Other factors such as accessibility, the availability of raw material and labour, labour wages, infrastructure, and security may play important roles in deciding the manufacturing location. In view of this, it is better to offer SMEs a holistic investment incentive which includes tax incentive, subsidies, infrastructures, security, an easy approval of grants, and the like. 
As for the age of SMEs, the results showed that the longer the years of operation of an SME, the more they prefer other locations than Sungai Petani. This is a good finding because in this case, it will reduce the congestion of SMEs in Sungai Petani. Indirectly, this will help the state in developing other areas in Kedah. These older established SMEs can then be encouraged to diversify and to branch out to other non-Sungai Petani areas. So, the authorities may priorities these older SMEs' applications to open branches in other areas as a form of encouragement.

The empirical results also indicated that if the products are distributed to the local market, the SMEs would tend to choose Sungai Petani as their operation centre. So, the government may need to maintain and upgrade the physical infrastructure and accessibility of the location from time to time. The toll fee increase may be kept to a minimum to avoid the increase of transport cost which may affect these SMEs in the supply of their products to the local markets, such as to Penang and northern Kedah. To enhance the distribution of SMEs' products to the local market, PLUS may give those who use the highway frequently some discount on toll fees.

\section{END NOTES}

1. Location incentive refers to tax incentives such as tax breaks, tax exemptions, or tax reduction.

2. Non-policy variables include measures of political stability, culture, infrastructure levels, wage rates, etc. Refer Loree and Guisinger (1995) for further elaboration.

3. The incentive provided for industries to locate in a development area and was linked to some of the incentives provided under the Investment Incentives Act 1968. For pioneer industries locating in a development area, an additional year of tax relief was granted irrespective of the size of the capital investment. Also, should an electronics firm which enjoyed the special incentive for the electronics industry be located in a development area, it would become eligible for an additional year of tax relief. For a company that had been granted the investment tax credit (ITC), an additional credit of $5 \%$ of the approved capital expenditure would be granted if the company were to be located in a development area (Lee, 1978, pp. 456-458). 
4. In addition to the development area in the Investment Incentive Act 1968, any industry located in the gazetted location incentive scheme became eligible for five years of tax relief compared with three years tax relief if the industry was located in the development area. Areas covered under Location Incentive Act were overlapped with the location under development area in the Investment Incentive Act, 1968 (Asan, 2004, p. 77).

5. It was hoped these additional incentives would decrease the cost of production. States in the East-Coast of Peninsular Malaysia recorded less comparative advantage in terms of concentration of population (consumer), labour force (high out-migration, especially those who are experienced and educated), and social infrastructure (Asan, 2004, p. 157).

In 1996 (July), from 4,403.47 total hectares industrial land developed under Johor State Economic Development Corporation (SEDC), only 16.59 hectares $(0.38 \%)$ were located at Mersing Industrial Estates (Mersing I), while, in 1998 (January), from 4,443.78 total hectares industrial land developed under SEDC, only 1,500 hectares $(0.33 \%)$ were located at Mersing Industrial Estates (Mersing II) (Asan, 2004, p. 163).

In 1995, the Malaysian Industrial Development Authority (MIDA) used term Free Zone (FZ), in current publications, MIDA uses term Free Industrial Zones (FIZs). FIZs enable these exportoriented companies to enjoy minimal customs formalities and duty free import of raw materials, component parts, machinery, and equipment required directly in the manufacturing process, as well as minimal formalities in exporting their finished products. Companies can be located within FIZs when: (a) their entire production or not less than $80 \%$ of their products are meant for export and (b) they mainly import their raw materials/components. Nevertheless, the government encourages FIZ companies to use local raw materials/components (MIDA, 2002, p. 92) (Asan, 2004, p. 167).

\section{ACKNOWLEDGMENT}

We would like to thank the anonymous referee whose comments have substantially improved this paper. 


\section{REFERENCES}

Asan, A. G. H. (2006). Disadvantage cycle in the less developed states: Evidence from Malaysia. International Journal of Management Studies, 13(1), 95-129.

Asan, A. G. H. (2004). Growth, structural change and regional inequality in Malaysia. Aldershot: Ashgate Publishing.

Brue, L. S. (2000). The evolution of economic thought. US: The Dryden Press.

Buurman J., \& Rietveld, P. (1999). Transport infrastructure and industrial location: The case of Thailand. RURDS, 11(1), 45 - 62.

Carod, J. M. A., \& Antolin, M.C.M. (2004). Firm size and geographical aggregation: An empirical appraisal in industrial location. Small Business Economics, 22(3/4), 299 - 312.

Chapman, C., \& Walker, D. (1987). Industrial location. Oxford: Basil Blackwell.

Chung, W., \& Alcacer, J. (2002). Knowledge seeking and location choice of foreign direct investment in the United States. Management Science, 48(12), 1534 - 1554.

Coughlin, C. C., \& Segev, E. (2000). Location determinants of new foreign-owned manufacturing plants. Journal of Regional Science, 40(2), 323 - 351.

Epping, G. M. (1982). Important factors in plant location in 1980. Growth and Change, April, 47 - 51.

Gabe, T. M., \& Bell, K. P. (2004). Tradeoffs between local taxes and government spending as determinants of business location. Journal of Regional Science, 44(1), 21 - 41.

Glaeser, E. L., Kallal, H.D., Scheinkman, J.A., \& Shleifer, A. (1992). Growth of cities. Journal of Political Economy, 100, 1126-1152.

Granger, M. D., \& Blomquist, G. C. (1999). Evaluating the influence of amenities on the location of manufacturing establishments in urban areas. Urban Studies, 36(11), 1859-1873.

Greenhut, M. L. (1995). Location economics: Theoretical underpinnings and applications. Edward Elgar Publishing.

Guimaraes, P., Figueiredo, O., \& Woodward, D. (2004). Industrial location modeling: Extending the random utility framework. Journal of Regional Science, 44(1), 1-20.

Hanson, G. H. (1996). Integration and location of activities: Economic integration, intra-industry trade, and frontier regions. European Economic Review, 40, 941-949.

Hayter, R. (1998). The dynamics of industrial location. The factory, the firm and the production system. New York: John Wiley and Sons. 
Karakaya, F., \& Canel, C. (1998). Underlying dimensions of business location decisions. Industrial Management an Data Systems, 7, 321329.

Lee, H. L. (1978). Public policies and economic diversification in West Malaysia. Kuala Lumpur: University of Malaya Publication.

Lindsey, V. W. (2004). The vulnerability of using tax incentives in Wisconsin. Marquette Law Review, 88(1), 107-129.

Loree, D. W., \& Guisinger, S. E. (1995). Policy and non-policy determinants of U.S. equity foreign direct investment. Journal of International Business Studies, 26(2), 281 - 299.

Lucas, R. E., Jr. (1993). Making a miracle. Econometrica, 61, 251-272.

MacCarthy, B. L., \& Atthirawong, W. (2003). Factors affecting location decisions in international operations - A Delphi Study. International Journal of Operations an Production Management, 23(7), 794-818.

Malaysia investment in the manufacturing sector: Policies, incentives and facilities. Kuala Lumpur: MIDA.

McCann, P., \& Shefer, D. (2004). Location, agglomeration, and infrastructure. Papers in Regional Science, 83, 177-196.

-McKendrick, D. G., Doner, R. F., \& Haggard, S. (2000). From silicon valley to Singapore: Location and competitive advantage in the hard disk drive industry. US: Stanford University Press.

Miller, E. W. (1970). A geography of industrial location. US: Wm. C. Brown Company Publishers.

Malaysia (2005). Ninth Malaysia Plan 2005-2010. KL: Malaysia's Economic Planning Unit.

Temple, M. (1996). Regional economic. (2nd ed.). London: MacMillan Press.

Townror, P. M. (1976). Planning industrial location. London: Leonard Hill. Wu, F. (2000). Modelling intrametropolitan location of foreign investment firms in a Chinese city. Urban Studies, 37(13), 2441-2464. 


\section{APPENDIX 1}

Multinomial logistic regression

Number of obs

$\begin{array}{ll}\text { Wald chi2 }(14) & = \\ \text { Prob > chi2 } & = \\ \text { Pseudo R2 } & =\end{array}$

$=$

Log pseudolikelihood $=-17.027027$

Pseudo R2

0.6834

\begin{tabular}{|c|c|c|c|c|c|c|}
\hline LOCATION_2 & Coef. & $\begin{array}{l}\text { Robust } \\
\text { Std. Err. }\end{array}$ & $z$ & $P>|z|$ & [ $95 \%$ Conf & Interval] \\
\hline $\begin{array}{r}\text { WORKERS } \\
\text { AGE } \\
F \text { RAW MAT } \\
\bar{F} \text { LAB OBOR } \\
F \text { INFRAI } \\
F \text { TND CLU } \\
\text { F SECURITY } \\
\bar{S} \text { OTHERSI } \\
\text { OWNERSHI P } \\
\text { DI STRI BUTI ON } \\
\text { GRANTS } \\
\text { - CONS }\end{array}$ & $\begin{array}{r}. .0044084 \\
8500007 \\
-39.65988 \\
2.719891 \\
-3.321558 \\
-2.508215 \\
43.33554 \\
-.9765298 \\
-2.544972 \\
-75.83138 \\
-1.759805 \\
-9.760667\end{array}$ & $\begin{array}{r}.0163662 \\
2814939 \\
2.21509 \\
1.432286 \\
1.987614 \\
1.679394 \\
4.466935 \\
2.575968 \\
1.377374 \\
2.869894 \\
1.364379 \\
2.89153\end{array}$ & $\begin{array}{r}-0.27 \\
3.02 \\
-17.90 \\
1.90 \\
-1.67 \\
-1.49 \\
9.70 \\
-0.38 \\
-1.85 \\
-26.42 \\
-1.29 \\
-3.38\end{array}$ & $\begin{array}{l}0.788 \\
0.003 \\
0.0000 \\
0.0558 \\
0.095 \\
0.135 \\
0.0000 \\
0.705 \\
0.0655 \\
0.0000 \\
0.1997 \\
0.001\end{array}$ & $\begin{array}{l}-.0364855 \\
.2982829 \\
-44.00138 \\
-.0873373 \\
-7.217209 \\
-5.799767 \\
34.58051 \\
-6.025335 \\
-5.244576 \\
-81.45626 \\
-4.433939 \\
-15.42796\end{array}$ & $\begin{array}{r}.0276688 \\
1.401719 \\
-35.31838 \\
5.52712 \\
.5740935 \\
.7833366 \\
52.09057 \\
4.072276 \\
.1546317 \\
.70 .20649 \\
.9143289 \\
.4 .093373\end{array}$ \\
\hline $\begin{array}{r}\text { WORKERS } \\
\text { AGE } \\
\text { F RAW MAT } \\
\bar{F} \text { LAB BOUR } \\
F \text { INFRAI } \\
F \text { TND CLU } \\
F \text { SECURITY } \\
\bar{F} \text { OTHERSI } \\
\text { OWNERSHI P } \\
\text { DI STRI BUTI ON } \\
\text { GRANTS } \\
\text { CONS }\end{array}$ & $\begin{array}{r}.0778156 \\
2544886 \\
49.80224 \\
-17.69078 \\
23.11596 \\
23.37102 \\
.8651099 \\
13.69085 \\
1.010662 \\
-.3178679 \\
28.24397 \\
-58.70867\end{array}$ & $\begin{array}{l}.0356771 \\
1297268 \\
3.805966 \\
6.151084 \\
1.940863 \\
5.350806 \\
2.146314 \\
3.39797 \\
1.885387 \\
1.561589\end{array}$ & $\begin{array}{r}2.18 \\
1.96 \\
13.09 \\
-2.88 \\
11.91 \\
4.37 \\
0.40 \\
4.03 \\
0.54 \\
-0.20\end{array}$ & $\begin{array}{l}0.029 \\
0.050 \\
0.000 \\
0.004 \\
0.000 \\
0.000 \\
0.687 \\
0.000 \\
0.592 \\
0.839\end{array}$ & $\begin{array}{r}.0078897 \\
.0002287 \\
42.34269 \\
-29.74669 \\
19.31193 \\
12.88364 \\
-3.341588 \\
7.030937 \\
-2.684629 \\
-3.378525\end{array}$ & $\begin{array}{r}.1477415 \\
5087485 \\
57.2618 \\
-5.63488 \\
26.91998 \\
33.85841 \\
5.071808 \\
20.35075 \\
4.705954 \\
2.742789\end{array}$ \\
\hline
\end{tabular}

(Out come LOCATION_2 ==1 is t 